\title{
Domy zdrowotno-wypoczynkowe
}

\section{Stowarzyszenia Chrześcijańsko-Narodowego Nauczycielstwa Szkół Powszechnych w okresie międzywojennym}

\author{
Joanna Zagdańska \\ Wydział Turystyki i Rekreacji, Akademia Wychowania Fizycznego J. Piłsudskiego w Warszawie, \\ ul. Marymoncka 34, 00-968 Warszawa, joanna-zagdanska@wp.pl
}

\begin{abstract}
Streszczenie
Lata zaborów, a przede wszystkim czas trwania I wojny światowej spowodowały znaczne pogorszenie stanu zdrowotności narodu polskiego. Sytuacja wymagała radykalnych działań i ogromnych nakładów finansowych. Tymczasem nowo odrodzone państwo polskie miało bardzo znikome środki na stworzenie w pełni profesjonalnej służby zdrowia. Oczekiwano więc - od różnego rodzaju środowisk pracujących zawodowo współuczestnictwa w organizacji ogólnopolskiego frontu walki o zdrowie i wypoczynek obywateli. Pierwszym środowiskiem, które pięknie wsparło w tym zakresie rząd polski byli nauczyciele, zrzeszeni w kilku organizacjach i stowarzyszeniach. Wśród nich było Stowarzyszenie Chrześcijańsko-Narodowe Nauczycielstwa Szkół Powszechnych, powstałe we wrześniu 1921 roku. Efektem dobrowolnych opodatkowań przedstawicieli tej patriotyczno - narodowej organizacji było wybudowanie, a następnie utrzymywanie Domów Zdrowia w Sewerynówce pod Szczawnicą i w Zakopanem oraz Domu Wypoczynkowego w Jastrzębiej Górze. Niektóre z tych ośrodków funkcjonują po dzień dzisiejszy.
\end{abstract}

\section{Stowa kluczowe}

dom zdrowia, dom wypoczynkowy, okres międzywojenny, stowarzyszenie, nauczyciele

\section{Wprowadzenie}

Okres II Rzeczypospolitej Polskiej (1918-1939) wiązał się z ogromnym wysiłkiem narodu na rzecz tworzenia instytucji i placówek zajmujących się problematyką różnych dziedzin życia społecznego, w tym również profilaktyki zdrowotnej, turystyki i rekreacji. Lata zaborów, a przede wszystkim czas trwania I wojny światowej spowodowały znaczne pogorszenie stanu zdrowotności narodu polskiego. Swego rodzaju plagą były choroby płuc i dolegliwości reumatyczne. Sytuacja wymagała radykalnych działań i ogromnych nakładów finansowych. Tymczasem nowo odrodzone państwo polskie miało bardzo znikome środki na stworzenie w pełni profesjonalnej służby zdrowia. Oczekiwano więc od różnego rodzaju środowisk pracujących zawodowo - współuczestnictwa w budowaniu ogólnopolskiego frontu walki o zdrowie i wypoczynek obywateli.

Pierwszym środowiskiem, które pięknie wsparło w tym zakresie rząd polski byli nauczyciele, którzy w drodze dobrowolnych opodatkowań (1\% od poborów) na początku lat dwudziestych XX wieku rozpoczęli akcję zbierania środków finansowych na budowę „swoich” sanatoriów, domów zdrowia, domów wypoczynkowych, pensjonatów i ośrodków turystycznych. Akcja trwała 
przez cały okres międzywojenny i przyniosła nadzwyczaj okazałe efekty. Jej swego rodzaju symbolem było sanatorium Związku Polskiego Nauczycielstwa Szkół Powszechnych w Zakopanem, oddane do użytku na początku 1926 roku, będące największym tego typu obiektem na świecie, wzniesionym w trybie powszechnego ofiarodawstwa jednej grupy zawodowej. To, że nauczyciele polscy byli pionierami społecznej walki o zdrowie i wypoczynek obywateli, w okresie międzywojennym wydawało się czymś zupełnie naturalnym. Wszak to od nich oczekiwano szerzenia nowoczesnej oświaty szkolnej i pozaszkolnej, gdzie zdrowie, rekreacja i wypoczynek zajmowały poczesne miejsca (Wczoraj... 1937: 3-4). Trzeba przy tym pamiętać, że środowisko nauczycielskie II RP, nie było grupą zawodową społecznie i politycznie jednolitą. Z chwilą odzyskania niepodległości w Polsce funkcjonowało ponad 180 różnego rodzaju związków i stowarzyszeń nauczycielskich, zrzeszających około 90.0oo nauczycieli szkół powszechnych, średnich i wyższych. W ciągu kilkunastu miesięcy po wyzwoleniu udało się jednak stworzyć trzy główne organizacje, zrzeszające około 80\% wszystkich nauczycieli. Najliczniejszą z nich był Związek Polskiego Nauczycielstwa Szkół Powszechnych (ZPNSP), powstały w kwietniu 1919 roku. Do tej grupy zaliczało się też Stowarzyszenie Chrześcijańsko - Narodowe Nauczycielstwa Szkół Powszechnych ${ }^{1}$, powstałe we wrześniu 1921 roku w wyniku połączenia dziewięciu organizacji nauczycielskich (Usiądek 1998: 6), liczące w 1926 roku około 12.026 członków, zrzeszonych w 316 kołach i 12 oddziałach (Sprawozdanie... 1928: 28). Organem prasowym stowarzyszenia był "Nauczyciel Polski” - dwutygodnik, a następnie miesięcznik wydawany we Lwowie, w mieście - które stanowiło główną bazę funkcjonowania SCNNSP. Zgodnie ze statutem stowarzyszenia celem jego działalności

1 W latach 1921-1939 prezesem Zarządu Głównego ZPNSP był znany działacz antykomunistyczny Michał Siciński (1874 - 1941). było między innymi: zjednoczenie ogółu polskiego nauczycielstwa szkół powszechnych dla rozwoju tegoż szkolnictwa oraz dla spraw wychowania publicznego i domowego w duchu chrześcijańskim i narodowym, systematyczne podnoszenie godności stanu nauczycielskiego oraz tworzenie domów zdrowia, domów wypoczynkowych i burs dla dzieci członków. Członkami SCNNSP mogli być tylko nauczyciele narodowości polskiej wyznania chrześcijańskiego (Statut... 1928).

Stowarzyszenie w swoich założeniach programowych zabiegało o trzyletnią szkołę powszechną, po ukończeniu której uczniowie mieli uczyć się w sześcioletniej szkole wydziałowej, przygotowującej młodzież do „życia praktycznego” (Kierski 1925: 470). Zdaniem członków organizacji wychowanie powinno być narodowe i moralne (II Walny... 1922: 5), oparte na zasadach chrześcijańskich, „postępujące z duchem czasu i pilnie strzegace interesów państwa” (Zasady... 1922: 73). W niektórych dokumentach pisano wprost, że „wychowanie religijno - moralne jest podstawą wychowania państwowego" ( $Z$ naszego... 1932: 4), a „wiara to fundament narodu" (Sprawozdanie... 1931: 16).

Latem 1924 roku Walny Zjazd stowarzyszenia podjął uchwałę, że każdy członek SCNNSP ma „dobrowolnie” przekazywać na rzecz "Samopomocy Koleżeńskiej” $1 \%$ swoich miesięcznych poborów (Po zjeździe... 1925: 6). W kompetencjach Samopomocy mieściła się też budowa, a następnie utrzymywanie domów zdrowotno - wypoczynkowych.

Celem niniejszego opracowania jest zaprezentowanie zupełnie dziś nieznanej problematyki budowy i organizacji nauczycielskich domów zdrowotno - wypoczynkowych oraz pełnienia przez nich roli w systemie profilaktyki zdrowotnej dydaktyków zrzeszonych w SCNNSP. Do napisania artykułu wykorzystano informacje, opracowania i teksty zamieszczane w wydawnictwach, akcydensach, gazetach i czasopismach okresu międzywojennego oraz kilka opracowań współczesnych. 


\section{Dom Zdrowia im Edmunda Cenara w Szczawnicy}

Zainteresowanie problematyką profilaktyki zdrowotnej w środowisku działaczy społecznych pojawiło się już kilkanaście miesięcy po powstaniu stowarzyszenia. Na początku 1923 roku Michał Korczak na łamach „Nauczyciela Polski” napisał: „Do osiągnięcia szczytnych celów potrzebny jest niejednokrotnie zbiorowy wysiłek. Nie możemy dziś jeszcze wymagać od Państwa świadczeń odpowiednich do ogromu potrzeb w czasie choroby własnej czy w rodzinie. Państwo ma bowiem inne nie mniej ważne zadania do spełnienia. Musimy zatem pomóc sobie sami i liczyć tylko na siebie. Poza pomocą lekarską potrzeba nam zakładów leczniczych, to znaczy sanatoriów, domów zdrowia i domów wypoczynkowych" (Korczak 1923: 2). W tym czasie chętnie przywoływano przykład działającego na terenie zaboru austriackiego Polskiego Towarzystwa Pedagogicznego, które w roku 1914 własnym kosztem „doprowadziło pod dach” budowę drewnianego domu zdrowia w Lubieniu (dziś województwo małopolskie). Ośrodek - posiadający dostęp do wód „siarczanych” - przeznaczony był dla chorych na reumatyzm nauczycieli i członków ich rodzin. Niestety obiekt ostatecznie nigdy nie został otwarty, bowiem spłonął zanim skończyła się pierwsza wojna światowa (Korczak 1923: 2)..

Szansa na uruchomienie nauczycielskiego domu zdrowia pojawiła się w roku 1923 w Sewerynówce położonej w pobliżu Szczawnicy (dziś jest to osiedle tego miasta), której właścicielem i zarządcą był wówczas hrabia Adam Stadnicki (1882-1982) (Węglarz 2008). Ten niezwykle patriotycznie usposobiony ziemianin czynił bardzo wiele, aby jego posiadłości notowały dynamiczny rozwój społeczno - gospodarczy. Jedną z dróg osiągania sukcesów w tej dziedzinie A. Stadnicki uczynił budowanie i modernizacja zdrojowisk szczawnickich (Stadnicki 2015). Starał się również zachęcić przedstawicieli innych regionów kraju do podejmowania inwestycji na ... ziemi im podarowanej. Jednym z „beneficjentów” było
SCNNSP, które wiosną 1923 roku otrzymało nieodpłatnie w Sewerynówce, położonej nad potokiem Sopotnickim w iglastym lesie, w odległości 4 km od Szczawnicy 3 morgi placu, pod budowę domu zdrowia. Główną atrakcją turystyczną Sewerynówki - już w okresie międzywojennym - był tutejszy malowniczy wodospad "Zaskalnik” i liczne szlaki wędrówek górskich.

W tym samym czasie akces podarowania stowarzyszeniu 20 morgów ziemi zgłosił też senator Ludwika Hammerling. Potencjalna darowizna znajdowała się w Brodach, położonych przy szosie Kalwaria - Bielsko, 40 km od Krakowa. Krótkotrwałe negocjacje nie przyniosły pozytywnego rozstrzygnięcia, bowiem proponowana „posiadłość” - zdaniem kierownictwa stowarzyszenia - leżała w mało atrakcyjnej pod względem zdrowotno - turystycznym miejscowości (Nasza akcja... 1924: 10). W takich okolicznościach cały wysiłek organizacyjno - finansowy został skierowany na plac w Sewerynówce, postrzeganej w kategoriach „osady” uzdrowiskowej. Zadaniem „pilotowania” inwestycji obarczono lwowski Oddział SCNNSP. Dla ułatwienia wykonania „polecenia” przy Zarządzie Głównym stowarzyszenia utworzono sekcję, która miała wspierać działania lwowskich budowniczych (Dom Zdrowia.. 1926: 13). Kilka miesięcy później komórka ta została przekształcona w Komitet Wykonawczy. Do końca 1923 roku głównie w środowisku lwowskich nauczycieli prowadzono zbiórkę środków finansowych i gromadzono niezbędne materiały budowlane. Część drewna pozyskano nieodpłatnie z lasów, będących własnością rodziny Stadnickich. W marcu 1924 roku ruszyły pierwsze prace inwestycyjne.

Uroczyste otwarcie parterowego, z wysokim „mieszkalnym” poddaszem Domu Zdrowia, wzniesionego z drewna na kamiennej podbudówce, w stylu zakopiańskim miało miejsce 1 lipca 1924 roku. Na obu flankach budynku umieszczone były obszerne werandy. W jednym czasie mogło $-\mathrm{w}$ jego 24 pokojach - mieszkać 48 osób (Nasza akcja... 1924: 10). Ośrodek nazwano imieniem 
Edwarda Cenara, który w roku 1892 przywiózł z Anglii do Lwowa pierwszą piłkę futbolową. Lwowski nauczyciel i działacz społeczny Towarzystwa Szkół Ludowych był też pionierem wychowania fizycznego i współzałożycielem Towarzystwa Gimnastycznego "Sokół” (Dom Zdrowia... 1924: 5-6). Nowo otwarty Dom Zdrowia miał być wykorzystywany każdego roku od maja do września i służyć głównie chorym na astmę nauczycielom, katechetom i członkom ich rodzin ( $Z \dot{z} y c i a \ldots$ 1925: 11). Zgodnie z opracowanym regulaminem wprowadzone trzy turnusy pobytu. Pierwszy rozpoczynał się 15 maja i trwał do 30 czerwca. Drugi od 1 lipca do 15 sierpnia i trzeci - od 16 sierpnia do 30 września. W sezonie pierwszym i trzecim jednodniowa opłata „łóżka” w pokoju jedno osobowym i całodziennego wyżywienia wynosiła $5,5 \mathrm{zł}, \mathrm{w}$ pokoju dwu osobowym $-5,25$ zł i w trzy osobowym -5 zł. W sezonie drugim odpowiednio: 6 zł, 5,8 i 5,7 zł. Prośby o pobyt w ośrodku należało kierować do Zarządu Głównego stowarzyszenia. Do dokumentu należało dołączyć zaświadczenie lekarskie, że „stan zdrowia nie przedstawia niebezpieczeństwa dla otoczenia" (Kronika... 1925: 6).

Od roku 1930 prośby o miejsce w Domu Zdrowia należało kierować już bezpośrednio do Zarządu Koła SCNNSP we Lwowie (ul. Zimorowicza 17). „Pojawiła” się konieczność wniesienia zadatku w wysokości 50 zł. W tym czasie zaczęły obowiązywać dwa terminy pobytu. Pierwszy od 1 do 31 lipca i drugi od 1 do 31 sierpnia. Innowacją było wprowadzenie etatu "lekarza ordynującego" (Oddziat Lwowski... 1931: 8). W efekcie nieco wzrosły ceny pobytu w ośrodku. Opłata w pokoju jednoosobowym z całodziennym wyżywieniem dla członów stowarzyszenia wynosiła $9 \mathrm{zł}$, a w pokojach dwu i trzyosobowych - po 8 zł. Dla osób nie będących członkami stowarzyszenia dzienna taryfa pobytu z utrzymaniem wynosiła 12 zł. Swego rodzaju niedogodnością był wymóg przywożenia ze sobą pościeli. Na wyposażeniu ośrodka w tym czasie było już radio, pianino i różnego rodzaju gry towarzyskie, a transport do Szczawnicy zapewniały regularnie „kursujące” furmanki (Dom Zdrowia... 1930: 7).

Kolejne zmiany miały miejsce w 1932 roku. Między innymi powrócono do korzystania $\mathrm{z}$ ośrodka przez cztery miesiące, to jest od 1 czerwca do 30 września. Zrezygnowano też z pomysłu zatrudniania etatowego lekarza. W związku z tym zmniejszona została wysokość opłat. W czerwcu i we wrześniu całodzienne utrzymanie w pokoju jedno osobowym kosztowało $5,5 \mathrm{zł}$, a w pozostałych pokojach po $4,8 \mathrm{zł}$. Zmniejszono też do 30 zł wysokość zadatku (Dom Zdrowia... 1932: 9-10). W roku 1934 - niezależnie od okresu - dzienny pobyt kosztował już w pokoju jedno osobowym 5 zł, a w pozostałych pokojach 4,5 zł ( $Z \dot{z} y c i a \ldots$ 1934: 5). Kolejna obniżka cen miała miejsce w roku 1936. Pobyt w pokoju jedno osobowym kosztował 4,5 zł, a w pozostałych pokojach - 4,1 zł. Można też było zapłacić 120 zł „ryczałtowo” za 30 dni, co było szansą na kolejne zmniejszenie kosztów pobytu w Sewerynówce (Gdzie spędzić... 1936b: 4).

Wprowadzane udogodnienia i systematyczne obniżki cen pobytu wynikały z faktu, że Dom Zdrowia w Sewerynówce nie był ośrodkiem specjalnie obleganym. Podczas wakacji w 1924 roku z jego „usług” skorzystało zaledwie 18 osób. Reprezentowały one: Przemyśl, Skałat, Siedlce, Warszawę i Kołmyję (Nasza akcja... 1924: 10). W latach 1927 - 1931 z ośrodka korzystało przeciętnie około 40 osób. W roku 1935 Dom Zdrowia gościł już tylko 33 osoby (118o osobodni), z czego 12 było mieszkańcami województwa wielkopolskiego, 9 - lwowskiego, 8 - warszawskiego, 3 - śląskiego, 2 - krakowskiego, wileńskiego i wołyńskiego - po 1. Średni czas pobytu w ośrodku jednej osoby wyniósł 35,7 dni. W tym czasie etat administratora ośrodka zajmował Bolesław Ruhm, a funkcję gospodyni bezinteresownie pełniła Emilia Szczerbińska ze Lwowa (Sprawozdanie... 1936: 7). Te same osoby pełniły swoje funkcje w kolejnym roku, a w placówce przebywało wówczas 41 osób (1178 osobodni) (Sprawozdanie... 1937: 7). Średni 
czas pobytu każdego gościa ośrodka wyniósł zatem 28,6 dni. W roku 1937 funkcję administratora budynku przyjął Stanisław Ligęza. W tym czasie ośrodek odwiedziły 38 osoby (Sprawozdanie ... 1938: 6-7). W roku 1938 z usług Domu Zdrowia skorzystało 39 osób, a średni czas pobytu wyniósł niewiele ponad niewiele ponad 23 dni (Ze sprawozdania... 1939: 3). Zwraca uwagę fakt, że sukcesywnie zmniejszał się średni czas pobytu gości w Sewerynówce. W roku 1938 w odniesieniu do roku 1935 zmniejszył się on aż o 12 dni.

W roku 1926 utrzymanie Domu Zdrowia (wraz z inwestycjami) w Szczawnicy kosztowało 12.530 zł (Decydujace... 1926: 4). W roku 1933 „rozchody” zamknęły się kwotą 3.115 zł, a "przychody” - 3.141 zł (Sprawozdanie... 1934: 9). Z kolei w roku 1935 rozchody wyniosły $4.262 \mathrm{zł}$, a przychody - $4.779 \mathrm{zł}$ (Sprawozdanie... 1936: 7). W kolejnym roku te wartości kształtowały się na poziomie - odpowiednio: 3.535 zł i 4.941 zł (Sprawozdanie ... 1937: 7). W roku 1938 wpływy z działalności ośrodka wyniosły 4.329 zł, a wydatki - 3.459 zł (Ze sprawozdania... 1939: 3). Z powyższego zestawienia wynika, że Dom Zdrowia w Sewerynówce był „instytucją" finansowo samowystarczalną.

Mimo sukcesów „gospodarczych” z frekwencją w Domu Zdrowia nie było najlepiej. W latach 1925 - 1935 kształtowała się ona na poziomie 40 - 50\%. Być może głównym powodem takiego stanu rzeczy był brak w budynku elektryfikacji i ciepłej wody oraz kłopoty komunikacyjne związane z docieraniem do Szczawnicy, gdzie mieściła się baza zabiegowa. Oddział lwowski stowarzyszenia, a zwłaszcza jego Koło Lwowskie czynili bardzo wiele, aby ułatwić życie mieszkańcom Domu Zdrowia. Między innymi w bardzo swoisty sposób zareagowało na ciągłe utryskiwania „pobożnych” gości na utrudnienia związane z braniem udziału w nabożeństwach, odprawianych w dość odległym kościele szczawnickim. Problem był omawiany na „walnym zgromadzeniu” członków Koła Lwowskiego w dniu 8 maja 1932 roku. Gremium podjęło wówczas decyzję o zbudowaniu obok ośrodka drewnianej kaplicy, w której msze święte mogliby odprawiać kapłani dojeżdżający co jakiś czas ze ...Szczawnicy. Pomysł lwowskich nauczycieli bardzo spodobał się hrabiemu A. Stadnickiemu, który nie tylko przekazał nieodpłatnie leżący tuż obok Domu Zdrowia plac pod budowę kaplicy, ale i ufundował dla niej ornat, przybory mszalne, bieliznę ołtarzową, srebro na kielich i „Sacre-Coeur” (Lista ofiar... 1932: 10). Szybko więc powołano komitet budowy kaplicy, w skład którego weszło aż 26 osób. Wśród nich byli dwaj kapłani: ks. dr Adam Hausner i ks. Józef Kłos. W takich okolicznościach - należało tylko zebrać środki finansowe na budowę zaplanowanej kaplicy. W tej sprawie - 16 czerwca 1932 roku - na forum organu prasowego stowarzyszenia zamieszczono stosowny apel o dokonywanie wpłat i przekazywanie darów. W apelu znalazły się też słowa: „Dom Zdrowia w Sewerynówce położony jest na wzgórzu, otoczonym rozległym lasem szpilkowym. Najbliższy i jedyny kościół oddalony jest od niego o 4 $\mathrm{km}$. Odległość ta nie pozwala osobom starszym lub wątlejszego zdrowia na korzystanie z Mszy Świętej. To skłoniło Zarząd Koła Lwowskiego do podjęcia zamiaru zbudowania skromnej kapliczki z drewna tuż obok Domu Zdrowia. [...]. Zebrano już 450 zł, a koszt budowy wyniesie około $3.500 \mathrm{zł}$. Musimy sobie pomóc sami" (Z życia... 1932: 7-8). Zbiórka darowizn przebiegała bardzo sprawnie. Członkowie stowarzyszenia oprócz środków finansowych przekazywali też złote i srebrne precjoza, za które co jakiś czas w „Nauczycielu Polskim” organizatorzy akcji zamieszczali serdeczne podziękowania (Lista ofiar... 1933: 10). Do wiosny 1933 roku zebrano ponad 6.00o zł.

Wznoszenie kaplicy powierzono najlepszym szczawnickim cieślom ludowym: Łukaszowi Malinowskiemu i jego synowi Stanisławowi. Wspierali go Józef Ciesiełka i Marcin Wiercioch (Witkowski 1992: 3). Uroczyste poświęcenie i otwarcie kaplicy pod wezwaniem Najświętszej Matki Boskiej miało miejsce w 15 sierpnia 1933 roku (Samopomoc...1934a: 15). Stanęła ona przy skrzyżowaniu leśnych dróg, na wysokości 
600 m.n.p.m. Zbudowano obiekt na planie prostokąta, z niewielką wieżyczką nad dachem, zwieńczoną krzyżem. Wyposażeniem kaplicy były wykonane przez cieśli ludowe meble rzeźbione w drewnie, grupa figuralna „Meki Pańskiej' i płaskorzeźba przedstawiająca „Ukrzyżowanie”. Koszt budowy kaplicy zamknął się w kwocie 6.565 zł (39, s. 1). W czerwcu 1934 roku w gazecie nauczycielskiej napisano: „Zbudowana kaplica wyposażona jest w komplet urządzeń liturgicznych, co umożliwia księdzu - prefektowi bywanie w naszym domu i odprawianie nabożeństw" (Z życia... 1934: 5).

Wzniesiona kaplica - oprócz funkcji typowo religijnych - bardzo szybko stała się miejscową atrakcją turystyczną, którą odwiedzali również mieszkańcy bliższych i dalszych okolic. Był to już okres, gdy osoby przyjeżdżające do Domu Zdrowia realizowali ambitne wycieczki na Babią Górę, do Lubania, Czorsztyna i innych miejscowości. Zdarzały się nawet przypadki podejmowania prób uprawiania twórczości teatralnej, plastycznej, itp. (Wakacje... 1935: 8).

\section{Dom Zdrowia "Modrzejów" w Zakopanem}

Każde stowarzyszenie okresu międzywojennego chciało mieć swój dom zdrowia, pensjonat czy ośrodek wypoczynkowy w Zakopanem, utożsamianym z perłą polskich uzdrowisk. Również SCNNSP już wiosną 1925 roku podjęło staranie o nabycie w tym mieście willi, mogącej w jednym czasie pomieścić 50 osób ( $Z$ życia... 1925: 11). W tym celu do Zakopanego udała się specjalna delegacja nauczycieli, która „upatrzyła" sobie wystawioną na sprzedaż drewnianą willę „Modrzejów”, usytuowaną przy ul. Wierchowej 1, naprzeciwko Antonówki. Była ona „zamykającą” ciąg kilku podobnych parterowych budynków, ustawionych w jednym szeregu, przykrytych stromym dachem i zamieszkiwanym poddaszem, w stylu zbliżonym do zakopiańskiego. Nazwa willi przypominała o związkach tego miejsca z Heleną Modrzejewską (1840-1909), najwybitniejszą aktorką polską drugiej połowy
XIX i początku XX wieku. Rzeczywiście na tej działce w latach 1882 - 1884 dla Heleny Modrzejewskiej - mieszkającej na stałe w USA, ale systematycznie odwiedzającą Zakopane - wzniesiono willę „Modrzejów”, według projektu jej przyrodniego brata Adolfa Opidy. Niestety w roku 1898 w zimowej stolicy Tatr miał miejsce wielki pożar, który doszczętnie strawił willę „Modrzejów” i 16 innych domów przy Krupówkach (web-02).

W roku 1902 willa „Modrzejów” została odbudowana na tym samym - dwu morgowym - placu, przez mieszkającą na stałe we Francji Annę Chomicką. Wyżej wymieniona za środki uzyskane ze sprzedaży zakopiańskiej willi zamierzała kupić podobny budynek w okolicach Wiednia. Transakcja kupna - sprzedaży odbudowanej willi „Modrzejów" została zawarta 12 października 1925 roku. Ogólna cena zakupu wyniosła 155.00o zł, przy czym w dniu podpisania umowy stowarzyszenie wpłaciło 80.00o zł. Pozostałe 75.00o zł - po przewalutowaniu na dolary (po kursie 1 dolar $=5,96 \mathrm{zł}$ ) - nauczyciele mieli spłacić pół roku później, a więc do 12 kwietnia 1926 roku (Decydujące... 1926: 4). W przypadku niewywiązania się z warunków umowy nauczyciele mieli zapłacić właścicielce obiektu karę w wysokości 60 tysięcy zł i dokonać zwrotu willi. Kierownictwo stowarzyszenie przyjmując takie rozwiązanie miało świadomość faktu, że od 1 lipca 1924 roku trwała dobrowolna zbiórka środków finansowych w wysokości 1\% miesięcznych poborów na rzecz Samopomocy Koleżeńskiej. Te 6 miesięcy wydawało się terminem „bezpiecznym”, aby zebrać potrzebną kwotę w wysokości 75 tysięcy zł.

Pozostając w optymistycznych nastrojach członkowie Zarządu Głównego 1 grudnia 1925 roku zorganizowali uroczyste otwarcie Domu Zdrowia „Modrzejów”, na które zaproszono liczną grupę przedstawicieli różnych ministerstw z Warszawy. Zelektryzowany, posiadający centralne ogrzewanie i instalację wodno - kanalizacyjną budynek robił pierwszorzędne wrażenie. Nic też dziwnego, że od początku cieszył się bardzo dużym zainteresowanie środowiska 
nauczycielskiego. W 32 pokojach budynku, w jednym czasie mogło zamieszkać 60 osób. Planowano obiekt wykorzystywać przez cały rok, a średni czas pobytu jednego kuracjusza określono na $30 \mathrm{dni}$. Już 1 listopada 1925 roku na łamach „Nauczyciela Polskiego" ukazał się okólnik Zarządu Głównego, w którym określone zostały warunki pobytu w willi „Modrzejów”. W pierwszej kolejności z obiektu mieli korzystać osoby będące w początkowym stadium choroby płuc. Podania o przydział miejsc należało kierować do zarządów kół powiatowych. Do dokumentu należało także dołączyć świadectwo lekarskie o potrzebie leczenia klimatycznego, podobne zaświadczenie, że stan zdrowia nie przedstawia zagrożenia dla otoczenia oraz potwierdzenie przynależności do stowarzyszenia i regularnego opłacania składek. Koszt jednodniowego pobytu w ośrodku z wyżywieniem określono na 6 zł (Okólnik... 1925: 9). Opłata obejmowała również opiekę lekarską, bowiem stowarzyszenie zaangażowało do pracy w ośrodku dwie pielęgniarki i doktora Ludwika Fiszera, na co dzień dyrektora pobliskiego Sanatorium Polskiego Czerwonego Krzyża. Wspierał ich często inny lekarz tego sanatorium - Jan Follak (Opieka... 1926: 12). W okresie 1 grudnia 1925 r. - 15 września 1926 r. z porad lekarskich L. Fiszera skorzystało 129 osób, spośród 163 przebywających w tym czasie w ośrodku (Decydujące... 1926: 4).

Był to już okres, kiedy stowarzyszenie borykało się z ogromnymi kłopotami związanymi z koniecznością spłacenia zaległych 75 tysięcy zł. Przełom lat 1925/1926 okazał się początkiem wielkiego kryzysu gospodarczego, powodującego gwałtowne pogarszanie się sytuacji materialnej nauczycieli. To powodowało wielkie problemy z „egzekwowaniem” jedno procentowego podatku na rzecz stowarzyszenia. Już na początku 1926 roku w „Nauczycielu Polskim” zamieszczono odezwę w której znalazły się słowa: "Zarządzona od dnia 1 lipca 1924 roku zbiórka składek z poborów za zgodą Ministerstwa Wyznań Religijnych i Oświecenia Publicznego przez Inspektoraty Szkolne nie przyniosła do końca 1925 roku spodziewanych rezultatów. Nie wiedząc o tym Zarząd Główny zakupił realność w Zakopanem. Tymczasem druga ratę musimy spłacić do 12 kwietnia 1926 roku" (Odezwa do... 1926).

W tym czasie było już powszechnie wiadomo, że do 12 kwietnia stowarzyszenie nie jest w stanie wywiązać się ze swoich finansowych zobowiązań, tym bardziej że szalejąca inflacja spowodowała gwałtowny wzrost ceny dolara. I tak - już w marcu 1926 roku zamiast „ustalonych” 75 tysięcy zł, należało A. Chomickiej przekazać prawie 113 tysięcy zł (Cyfry... 1926: 4). Rozpoczęto zatem z byłą właścicielką willi serię dość nerwowych negocjacji. Nauczyciele zabiegali, aby ostateczna zapłata nastąpiła dopiero w październiku 1927 roku. A. Chomicka zdecydowanie odrzuciła tę propozycję. Ostatecznie zgodziła się jednak, aby zaległa rata została definitywnie spłacona (z odsetkami) do 12 kwietnia 1927 roku (Decydujace... 1926: 4).

Zarząd Główny już w maju 1926 roku podjął dynamiczną „ofensywę”, aby sprostać nowym ustaleniom. W organie prasowym stowarzyszenia zaczęto zamieszczać bardzo alarmujące prośby i odezwy, zobowiązujące nauczycieli do przekazywania każdego miesiąca 1\% swoich dochodów na rzecz Samopomocy Koleżeńskiej (Spetnijmy... 1926: 4). Niezależnie od tego w październiku 1926 roku ogłoszono pożyczkę wewnętrzną wśród członków stowarzyszenia, prosząc ich o wpłacenie jednorazowej kwoty w wysokości 20 zł. Prośba ta spotkała się z dużym zrozumieniem. Tylko w styczniu i lutym 1927 roku oddziały terenowe $-\mathrm{z}$ tego tytułu - przekazały: lwowski - 13.243 zł, poznański - $17.049 \mathrm{zl}$, warszawski $-5.601 \mathrm{zl}$, pomorski - 2.813 zł, łódzki - 2.245 zł, krakowski - 1.705 zł. Pozostałych sześć oddziałów przekazało w tym czasie po 1.2 - 1.5 tysiąca zł (Nasz Walny... 1927: 5). Pożyczka wewnętrzna miała być spłacona do 31 sierpnia 1930 roku ( $Z \dot{z}$ ycia... 1927a: 7).

Po opublikowanych prośbach i odezwach nieco lepiej przebiegać też zaczął proces zbierania środków z tytułu „miesięcznych” opodatkowań. Tylko w lutym i styczniu 1927 
roku do Zarządu Głównego wpłynęło z tego tytułu prawie 10 tysięcy zł, a w marcu - kolejne 3.522 zł ( $Z \dot{z} y c i a \ldots$ 1927b: 5). Mimo wielkiego zaangażowania wszystkich środowisk - nie obyło się jednak bez konieczności zaciągnięcia niewielkiej pożyczki (3o tysięcy zł) w Banku Związku Spółek Zarobkowych. W połowie 1927 roku Zarząd Główny z dumą oznajmił członkom SCNNSP, że wszystkie należności wobec A. Chomickiej zostały uregulowane, a „niebezpieczeństwo utraty włożonego w Modrzejów kapitału szczęśliwie zostało zażegnane" (Sprawozdanie... 1927, s. 7).

Niezależnie od „zawirowań” wokół spłacania należności zakopiański Dom Zdrowia radził sobie bardzo dobrze. Bezpośrednio jego pracą kierował wybrany w drodze przeprowadzonego konkursu administrator. Ważne funkcje pełnił też trzyosobowy „Zarząd Domu Zdrowia Modrzejów”. W 1926 roku z usług ośrodka skorzystały aż 542 osoby. Wpływy z tego tytułu wyniosły 62.953 zł, przy wydatkach równych 47.414 zł (Sprawozdanie, s. 7). W roku 1928 podjęto decyzję, że Dom Zdrowia w Zakopanem musi być „gospodarczo samowystarczalny”. W ramach realizacji tego postanowienia szybko wprowadzono jednorazową opłatę w wysokości 10 zł, z tytułu opieki lekarskiej (Przebieg... 1928: 7).

Mimo wprowadzenia tych niepopularnych przecież „innowacji”, ośrodek cieszył się ogromną popularnością. Na początku 1929 roku w organie prasowym stowarzyszenia napisano, że „Modrzejów” nie jest w stanie "przyjąć wszystkich zainteresowanych" $(Z \dot{z} y$ cia... 1929: 5). Wielkie powodzenie ośrodka spowodowało, że w roku 1931 zaczęto zgłaszać wizję rozbudowy kompleksu $(Z \dot{z} y c i a .$. 1931b: 5). Jak w tym czasie wyglądała willa „Modrzejów”, opisał jeden z jej gości. W „prezentacji” znalazły się słowa: „To biały pałacyk z widokiem na Giewont. Są tu służące, ciepła i zimna woda. Wokół bardzo serdeczna atmosfera- prawie jak w raju. [...]. Szerokie, jasno orzechowe schody i barierki oraz lśniąca podłoga, białe ściany i drzwi - nastrajają każdego pogodnie. Białe meble w pokojach, przypominają śnieg. Na pierwszym piętrze oglądamy plan ołtarza, który ma stanąć w zaprojektowanej kaplicy. Zapłacą za to członkowie Oddziału Poznańskiego. Na posiłki wzywa nas dzwonek. Wieczorem w saloniku - odbywają się koncerty" (Odpoczynek... 1931: 8-9).

W 1933 roku z ośrodka skorzystało 508 osób, z czego tylko 81 przybyło z tzw. kartą państwowej pomocy lekarskiej, upoważniającą do uzyskania 75\% dopłaty do kosztów pobytu w Domu Zdrowia ${ }^{2}$. Poważnie chorych lekarz naczelny L. Fiszer kierował do Sanatorium „Odrodzenie”. Był to okres, gdy w ośrodku zrealizowano kilka „inwestycji”. Między innymi zorganizowano bibliotekę, poprawiono dach budynku, zbudowano budynek gospodarczy i ogrodzenie (siatka na podmurówce), w pięciu pokojach położono parkiet i rozpoczęto wznoszenie leżalni. Wartość zgromadzonych w placówce „ruchomości’ szacowano na 31.000 zł. Funkcję zarządcy i kierownika administracji pełniła w tym czasie emerytowana nauczycielka Helena Bukarska (Samopomoc...1934b: 14).

W roku 1934. Dom Zdrowia odwiedziło 511 osób, a wpływy z tego tytułu wyniosły $46.671 \mathrm{zl}$. W sprawozdaniu napisano, że 90\% gości ośrodka - to „młody element nauczycielstwa” (Sprawozdanie... 1935: 1). W tym roku wartość ośrodka wyceniono na 234.719 zł (Sprawozdanie... 1935: 1).

W roku 1935 osoby posiadające kartę państwowej pomocy lekarskiej płaciły za jedno dniowy dzień pobytu po 2,75 zł, natomiast pozostali kuracjusze w zależności od miesiąca pobytu - od 4,5 do 6 zł ( $Z \dot{z} y c i a \ldots$ 1935: 9).

24 sierpnia 1926 roku ukazało się rozporządzenie Rady Ministrów o państwowej pomocy lekarskiej dla funkcjonariuszy państwowych. Co roku drukowany był wykaz sanatoriów i domów zdrowia, których kuracjusze posiadający skierowania powiatowych lekarzy mieli prawo do $75 \%$ dotacji Departamentu Zdrowia Ministerstwa Opieki Społecznej. Od roku 1932 na liście „instytucji” uprawnionych do otrzymywania refundacji był również Dom Zdrowia „Modrzejów”. 
W kolejnym roku nastąpiło załamanie dobrego okresu zakopiańskiej placówki. W tym czasie - zdaniem Zarządu Głównego - radykalnemu pogorszeniu uległy warunki materialne pedagogów (Sprawozdanie... 1937: 7). Towarzyszył temu proces redukcji zatrudnienia w szkolnictwie powszechnym, w wyniku czego nauczyciele nie chcieli wyjeżdżać poza rejon swego zamieszkania. W takich okolicznościach z Domu Zdrowia w roku 1935 skorzystało tylko 112 osób (Sprawozdanie... 1937: 7). Z pracy w ośrodku zrezygnował L. Fiszer. Jego miejsce z dniem 1 sierpnia 1936 roku zajął dr Edward Łotocki, pozostający na etacie Sanatorium Związku Pracowników Poczt, Telegrafów i Telefonów (Zmiana... 1936: 11). Zmieniali się także zarządcy placówki. Najpierw w terminie od 1 czerwca do 30 października 1935 roku ośrodkiem zarządzała Maria Lubowidzka, a następnie od 1 listopada 1935 roku Maria Piwocka (Sprawozdanie... 1936: 7). Nowe kierownictwo na początku 1936 roku podjęło decyzję, ze zakopiański Dom Zdrowia będzie funkcjonował tylko w okresie wakacji i w czasie świąt Bożego Narodzenia. Mimo tego w roku 1936 ośrodek zanotował bilans ujemny w wysokości $22.580 \mathrm{zł}$ (4901 osobodni), a w roku $1937-20.855$ zł (5922 osobodni) (Sprawozdanie... 1938: 6-7). Sytuacja zaczęła się nieco poprawiać dopiero w roku 1938, kiedy powrócono do całorocznego funkcjonowania ośrodka. Z Domu Zdrowia skorzystało w tym czasie 277 osób, a średni czas pobytu kształtował się na poziomie 23 dni (6281 osobodni). Mimo zdecydowanej poprawy wskaźnika frekwencji w porównaniu do dwóch lat poprzednich, w roku 1938 ośrodek zanotował finansowy bilans ujemny w wysokości 5.802 zł (Ze sprawozdania... 1939: 3).

\section{Dom Wypoczynkowy w Jastrzębiej Górze}

Organizując swoje domy zdrowia w środowiskach górskich, członkowie Zarządu Głównego myśleli też o utworzeniu podobnej placówki „nad Polskim Morzem”. Świetnym pretekstem do zgłoszenia tego typu inicjatywy było podarowaniu stowarzyszeniu pod koniec 1927 roku działki w Hallerowie przez znanego generała polskiego - Józefa Hallera $(1873$ - 1960) ( $Z \dot{z} y$ cia... 1928: 8). Nie był to jednak okres korzystny do otwierania kolejnego frontu inwestycyjnego. Kłopoty ze spłaceniem willi w Zakopanem, skutecznie torpedowały szybkie podjecie w tym zakresie decyzji. Do tematu powrócono wiosną 1930 roku, kiedy to podobną działkę budowlaną w pobliskiej Jastrzębiej Górze (dziś dzielnica Władysławowa), usytuowaną $100 \mathrm{~m}$ od brzegu morskiego, podarował SCNNSP Edward Potworowski ${ }^{3}$. Kierownictwo stowarzyszenia miało więc poważny problem z podjęciem decyzji o miejscu lokalizacji placówki. Ostatecznie jednak rozstrzygnięto, że Dom Zdrowia zostanie wzniesiony w Jastrzębiej Górze. $\mathrm{Na}$ Walnym Zjeździe organizacji uchwalono konieczność „dobrowolnego’ opodatkowania wszystkich członków stowarzyszenia na sumę 5 zł, która miała być wpłacona w terminie do 15 października 1930 roku (Sprawy... 1930: 9). Szybko opracowano też projekt i kosztorys budowy. Wkrótce okazało się jednak, że decyzja o jednorazowej wpłacie 5 zł, nie przyniosła oczekiwanych rezultatów. W „Nauczycielu Polskim” napisano wprost: „wpłaty na budowę Domu Zdrowia w Jastrzębiej Górze nie dopisały" ( $Z$ życia... 1931a: 8). W takiej sytuacji sprawę rozpoczęcia inwestycji „odroczono do końca 1932 roku" (Z życia... 1931a: 8).

Powrócono jednak do niej pół roku szybciej, bowiem już 27 sierpnia 1932 roku odbyła się uroczystość położenia i poświecenia kamienia węgielnego. Ceremonię tę celebrował i „cichą mszę” odprawił ks. Andrzej Krenecki, proboszcz ze Strzelna. Podczas uroczystości bardzo patetyczne przemówienie wygłosił prezes stowarzyszenia - Michał Siciński. W akcie erekcyjnym między

3 Edward Potworowski (1885-1939) - to znany ziemianin i działacz społeczny Wielkopolski. W roku 1923 został minowany tajnym szambelanem przez papieża Piusa XI. Na stałe mieszkał w Gostyniu Wielkim, gdzie został zamordowany przez Niemców 21.10.1939 roku. 
innymi znalazły się słowa: „W imię Boga Wszechmogącego, w Trójcy Świętej Jedynego i Najświętszej Marii Jego, Pani i Królowej Polski, na świadectwo niepodległości i samodzielności władania wszystkimi ziemiami zjednoczonymi dziś w jedną całość, w umiłowana nam ponad wszystko Ojczyznę, na pożytek członków Stowarzyszenia oraz całego nauczycielstwa polskiego, Zarząd Główny postanowił w myśl uchwały IX Walnego Zjazdu Stowarzyszenia na parceli darowanej przez szambelana J. Św. Ojca Św. Piusa XI Edwarda Potworowskiego dom ten na tej ziemi pomorskiej. Zarząd Główny Stowarzyszenia dokumentuje w ten sposób odwieczne prawo Polski do całego Pomorza. Stowarzyszenie pragnie przez wybudowanie tego domu stworzyć stałą placówkę, któryby obecnym i przyszłym pokoleniom nauczycielstwa unaoczniała znaczenie morza dla niepodległości i potęgi Najjaśniejszej Rzeczypospolitej Polskiej. Ten dom będzie strażnicą uczuć patriotycznych i ogniskiem hartu ducha w walce o nierozerwalność granic" (Nasz dom... 1932: 8-9). Tzw. stan surowy budynku miał być osiągnięty do końca 1932 roku. Realizację inwestycji powierzono firmie budowlanej Władysława Wrzalika z Poznania. Funkcję kierownika budowy pełnił inż. Jan Skotarek. Obiekt miał być oddany do użytku do końca czerwca 1933 roku.

Projekt zakładał wzniesienie murowanego, podpiwniczonego, modernistycznego, jednopiętrowego, przykrytego płaskim dachem budynku, z zamieszkiwanym poddaszem, z którego w jednym czasie mogło korzystać 60 osób. Na parterze obiektu miała znajdować się kuchnia z zapleczem gospodarczym, pokój administracyjny, salon klubowy i 6 pokoi mieszkalnych. Na piętrze miało być 10 pokoi dwuosobowych, 7 - jednoosobowych i duża jadalnia. Na poddaszu planowano zlokalizować pokoje dla „masowych wycieczek”, przystosowane do kwaterowania 2 - 4 osób. W wysokiej - posiadającej okna - piwnicy miały się znaleźć pokoje dla dozorcy i służby, spiżarnia, pralnia i pomieszczenia gospodarcze. Obiekt miał posiadać własną elektrownię, instalację wodno - kanalizacyjną i ogrzewanie „piecowe”. Inwestycja miała kosztować około 100.00o zł (web-01).

W chwili rozpoczynania inwestycji stowarzyszenie miało na ten cel zebrane tylko 21.00o zł. W takiej sytuacji obradujący w Częstochowie XI Walny Zjazd ustalił „rozpisanie” pożyczki wewnętrznej za wydaniem „Listów Dłużnych” na kwotę po 25 zł, oprocentowanych w Banku Polskim na 5 lat. Wpłaty na konto ZG w Warszawie mogły być dokonywane już od 1.10.1932 roku, a stowarzyszenie zaciągnięty dług miało spłacać po upływie trzech lat od chwili zakończenia budowy jastrzębskiego Domu Zdrowia (web-01). W ślad za podjętą uchwałą na łamach „Nauczyciela Polskiego” od października 1932 roku, do końca kwietnia 1933 roku trwała bardzo dynamiczna akcja "agitacji” na rzecz konieczności udzielenia stowarzyszeniu pożyczki wewnętrznej. Przeważnie zamieszczane odezwy, obwieszczenia i apele miały tytuły: „Czy już wpłaciłeś na Jastrzębią Górę?” (Czy już... 1932: 6), lub „Czy dopełniłeś już subskrypcji na budowę Domu Wypoczynkowego w Jastrzębiej Górze" (Nauczyciel... 1933).

Zmasowana akcja promocyjno - propagandowa tym razem przyniosła oczekiwany skutek. Uroczystość otwarcia ośrodka odbyła się zgodnie z planem 22 czerwcu 1933 roku. Miedzy innymi wzięli w nim udział wszyscy uczestnicy obradującego w dniach 19 - 21 czerwca 1933 roku w Gdyni XII Walnego Zjazdu Delegatów SCNNSP. Na tę okoliczność budynek został udekorowany "zielenią i biało - czerwonymi barwami". Uroczystość otwarcia Domu Wypoczynkowego - z udziałem 250 osób - rozpoczęła Mszą Świętą, odprawiona w kaplicy Ojców Jezuitów w Jastrzębiej Górze. Zebrani mieli też okazję wysłuchać informacji o genezie i historii budowy jastrzębskiej placówki wypoczynkowej. Tradycyjnie w wystąpieniu prezesa M. Sicińskiego znalazło się wiele akcentów religijno - patriotycznych i narodowo - niepodległościowych. Warto odnotować jego fragment: „Nowo otwierany Dom Wypoczynkowy - powiedział prezes stowarzyszenia - powstał z poczucia i nakazu 
patriotycznego dla zaznaczenia, iż na zagrożonym odcinku przez odwiecznych wrogów Zachodu stawiamy strażnice widomą, która ma świadczyć o zdecydowanej woli całego narodu obrony granic aż do utraty ostatniej kropli krwi. Pragniemy zamanifestować uczucie całej Polski o znaczeniu Bałtyku dla Państwa" (Na Jastrzębiej... 1933: 5). Bardzo znamiennie „wybrzmiewała” też treść telegramu wysłanym do Prezydenta RP, kończącego się zdaniem: „Stowarzyszenie zapewnia Pana Prezydenta o swojej niezłomnej woli oddania wszystkich sił w szerzeniu wśród młodzieży i społeczeństwa miłości do morza i wdrażania gotowości ofiary krwi w razie potrzeby w obronie nienaruszalności granic" (Na Jastrzębiej... 1933: 5).

Bezpośredni nadzór nad nowo otwartym Domem Wypoczynkowym powierzono Janowi Sobolewskiemu z Poznania, prezesowi Oddziały Wielkopolskiego SCNNSP. Administratorem ośrodka została Eugenia Bauerowa. Zgłoszenie na pobyt w ośrodku należało zgłaszać bezpośrednio do Zarządu Głównego, zajmującego lokal w Warszawie, przy ul. Senatorskiej 19. Ośrodek miał funkcjonować każdego roku od 1 czerwca do końca września. W roku 1933 z placówki skorzystało 196 osób, z czego tylko 30\% było członkami stowarzyszenia. Przychód z tego tytułu wyniósł 12.852 zł, a wydatki 10.239 zł (Sprawozdanie... 1934: 9).

Z korespondencji zamieszczonej latem 1935 roku w „Nauczycielu Polskim” wynika, że Dom Wypoczynkowy w Jastrzębiej Górze "staje się ośrodkiem propagandy i i wiedzy o polskim morzu" (Perta... 1935: 9). Jednodniowy pobyt z wyżywieniem kosztował wtedy $5 \mathrm{zł}$ w pokoju jednoosobowym i $4 \mathrm{zł}$ w pozostałych pokojach (Gdzie spedzić... 1936a: 9). Od roku 1936 nie trzeba już było do ośrodka przywozić własnej pościeli. W „przywołanym” 1936 roku, z usług placówki skorzystały 132 osoby. Średni czas pobytu wyniósł 18,3 dni. Największe przepełnienie ośrodka miało miejsce w lipcu. Wyliczono, że przeciętna frekwencja w całym sezonie wyniosła 52,3\%. Wpływy ośrodka wyniosły 13.652 zł, a wydatki - 11.992 zł (Sprawozdanie... 1937: 7).

W sezonie 1937 roku Dom Wypoczynkowy przyjął 153 osoby. Średni czas ich pobytu wyniósł prawie $20 \mathrm{dni}$, co dało wskaźnik wykorzystania obiektu na poziomie 58,3\%. Administratorem ośrodka była już w tym czasie Maria Włodarczykowa. Pod jej zarządem placówka uzyskała przychód w wysokości 15.585 zł, przy wydatkach - 10.427 zł (Sprawozdanie... 1938: 6-7). Jeszcze lepsze wyniki ośrodek zanotował w roku 1938. Przybyły do niego wówczas 162 osoby, a średni czas ich pobytu wyniósł 19 dni. Wpływy z tego tytułu wyniosły 18.211 zł, a wydatki - 12.409 zł. Poziom frekwencji oceniono na 61\% (Ze sprawozdania... 1939: 3). Można wiec przyjąć, że jastrzębska placówka - w porównaniu z Domem Zdrowia w Zakopanem - z roku na rok zwiększała swoją efektywność i odgrywała coraz większą rolę w systemie zorganizowanego wypoczynku SCNNSP.

\section{Wnioski}

Na koniec niniejszych rozważań trzeba też nadmienić, że niezależnie od wysiłków na rzecz tworzenia własnych ośrodków, kierownictwo stowarzyszenia co jakiś czas podejmowało też inicjatywy organizacji zbiorowego wypoczynku w miejscowościach, gdzie nie miało własnych placówek. W pierwszej kolejności trzeba wymienić Krynice Górską, w której SCNNSP doraźnie wynajmowało willę w centrum miasta (Kolonia.. 1930: 7). Na oddzielną uwagę zasługuje systematycznie prowadzona akcja kolonii wakacyjnych organizowana w budynkach szkolnych i adresowana do dzieci z rodzin nauczycielskich. Dzięki niej młodzież mogła prawie rokrocznie za symboliczna opłatą przebywać w różnych atrakcyjnych turystycznie i zdrowotnie - przeważnie nadmorskich i górskich - miejscowościach (Kolonie... 1933: 9).

Jednak najważniejszą rolę w nauczycielskim systemie profilaktyki zdrowotnej i wypoczynku odgrywały placówki utworzone w Szczawnicy, Zakopanem i Jastrzębiej 
Górze. To niewątpliwie znaczące pomniki ofiarności, patriotyzmu i determinacji środowiska nauczycielskiego okresu międzywojennego. Śledząc historię powstawania tych ośrodków odnieść można wrażenie, że dla nauczycieli ważniejszą kwestią była konieczność zbudowania lub zorganizowania domu zdrowia czy domu wypoczynkowego, niż problematyka przyjemności korzystania $\mathrm{z}$ ich uroku.

Czas drugiej wojny światowej nie był korzystny dla obiektów z takim trudem tworzonych przez środowisko nauczycielskie. W Domu Zdrowia w Sewerynówce mieszkali robotnicy leśni, przymusowo pracujący na rzecz okupanta. Tutaj również zapadały wyroki na konfidentów gestapo i działaczy "Goralenvolk". W roku 1944 budynek częściowo strawił pożar. Również dwa pozostałe ośrodki nauczycielskie przez wszystkie lata okupacji były wykorzystywane przez administrację niemiecką lub żołnierzy Wehrmachtu.

Po ustaniu działań wojennych wszystkie obiekty stały się własnością Związku Nauczycielstwa Polskiego. Dom Zdrowia w Sewerynówce w latach 1953 - 1958 służył jako magazyn hotelu robotników, pracujących przy budowie ujęcia wodnego. W wyniku braku odpowiedniej opieki, dom ten ulegał systematycznej dewastacji. W roku 1961 obiekt przejęło ministerstwo gospodarki komunalnej i mieszkaniowej, które rok później odbudowało budynek, z myślą o przeznaczeniu go na ośrodek wypoczynkowy związku zawodowego tego resortu. Niestety w lipcu 1962 roku - tuż przed otwarciem- obiekt doszczętnie spłonął. Dziś o jego istnieniu przypominają zarośnięte leśnymi chaszczami mury fundamentów.

Znacznie lepiej historia obeszła się z sąsiednią kaplicą. W czasie trwania wojny i przez kilkanaście lat po jej zakończeniu była ona nieczynna. Dopiero od roku 1967 regularnie - co jakiś czas - odprawiane są tu nabożeństwa. Niezależnie od tego - co roku 15 sierpnia - odbywają się tu uroczystości poświęcenia zbóż i produktów rolnych. W roku 1984 oficjalnym właścicielem kaplicy została parafia szczawnicka, a pracę nad uatrakcyjnieniem wnętrza obiektu podjął znany miejscowy rzeźbiarz ludowy Henryk Zachwieja (1952 - 2014). Efektem jego pracy są miedzy innymi: zwisający z sufitu drewniany żyrandol i drewniane płaskorzeźby sakralne noszące tytuły: „Boże Narodzenie”, "Chrystus Cierpiący" i "Zmartwychwstanie” (Witkowski 1992: 3).

W roku 1949 pierwotne funkcje użytkowe przywrócono również zakopiańskiej willi „Modrzejów”. Przy czym nie był to już dom zdrowia, tylko pensjonat wypoczynkowy Związku Nauczycielstwa Polskiego. W takim charakterze budynek był wykorzystywany do roku 2011, kiedy ZG ZNP postanowił go sprzedać prywatnej spółce hotelarskiej z Warszawy. W takich okolicznościach w marcu 2012 roku - mimo protestów wielu mieszkańców Zakopanego - doszło do zburzenia budynku. W najbliższym czasie ma tu stanąć okazały obiekt hotelowy (web-o2).

Na szczęście - kierownictwo ZNP nie pozbyło się jeszcze Domu Wypoczynkowego we władysławowskiej Jastrzębiej Górze, usytuowanego przy dzisiejszej ul. Bałtyckiej 30. Aktualna jego nazwa brzmi: Ośrodek Wypoczynkowy ZNP „Fregata”. Nad obiektem dysponującym pięćdziesięcioma miejscami noclegowymi i wykorzystywanym głównie w okresie letnim, bezpośrednią opiekę sprawuje Pomorski Okręg ZNP, z siedzibą w Gdańsku (web-o1). Przedwojenna bryła architektoniczna budynku nie została zmieniona, mimo przeprowadzenia kilku remontów modernizacyjno - adaptacyjnych. O jego pięknej historii sprzed osiemdziesięciu czterech lat dziś już prawie nikt nie pamięta.

Należy więc czynić wszystko, aby piękne tradycje środowiska nauczycielskiego nie odeszły bezpowrotnie w „świat zapomnienia”. 


\section{Bibliografia}

Cyfry dotyczace Samopomocy, 1926, Nauczyciel Polski, nr 8-10, 4.

Czy już wptaciłeś na Jastrzębią Górę?, 1932, Nauczyciel Polski, nr 17, 6.

Decydujące chwile, 1926, Nauczyciel Polski, nr 8-10, 4.

Dom Zdrowia dla nauczycieli, 1923, Nauczyciel Polski, nr 5-6, 13.

Dom Zdrowia im. Cenara w Szczawnicy, 1930, Nauczyciel Polski, nr 10, 7.

Dom Zdrowia im. Edwarda Cenara w Szczawnicy, 1924, Nauczyciel Polski, nr 9, 5-6.

Dom Zdrowia w Szczawnicy, 1932, Nauczyciel Polski, nr 9, 9-10.

Gdzie spędzić wakacje?, 1936a, Nauczyciel Polski, nr $7,9$.

Gdzie spędzić wakacje?, 1936b, Nauczyciel Polski, nr 3-4, 4 .

II Walny Zjazd Delegatów SCNNSP 28-3o grudnia 1922 r. w Warszawie, 1922, Nauczyciel Polski, nr $1-2,5$.

Kierski F., 1925, Podręczna encyklopedia pedagogiczna, t. 2, Lwów.

Kolonia wypoczynkowa, 1930, Nauczyciel Polski, nr 10, 7 .

Kolonie w Inowroctawiu, 1932, Nauczyciel Polski, nr 12, 9.

Korczak M., 1923, Sami sobie, Nauczyciel Polski, nr 4, 2.

Kronika Domu Zdrowia w Szczawnicy, 1925, Nauczyciel Polski, nr 6, 6.

Lista ofiar na budowe Kaplicy przy Nauczycielskim Domu Zdrowia w Sewerynówce obok Szczawnicy, 1932, Nauczyciel Polski, nr 16, 10.

Lista ofiar na budowę Kaplicy przy Nauczycielskim Domu Zdrowia w Sewerynówce obok Szczawnicy. Podziękowanie, 1933, Nauczyciel Polski, nr 6, 10.

Na Jastrzębiej Górze, 1933, Nauczyciel Polski, nr 13, 5. Nasz dom nad morzem, 1932, Nauczyciel Polski, nr 14, 8-9.

Nasz Walny Zjazd w Gdańsku, Z życia Stowarzyszenia, 1927, Nauczyciel Polski, nr 5, 5.

Nasza akcja budowy domów zdrowia, 1924, Nauczyciel Polski, nr 8, 10.

Nauczyciel Polski, 1933, nr 1-5 (odezwy i apele).

Oddziat Lwowski - Dom Zdrowia w Szczawnicy, 1931, Nauczyciel Polski, nr 9, 8.
Odezwa do członków Stowarzyszenia Chrześcijańsko-Narodowego Nauczycielstwa Szkót Powszechnych, 1926, Nauczyciel Polski, marzec (dodatek).

Odpoczynek w „Modrzejowie”, Z życia Stowarzyszenia, 1931, Nauczyciel Polski, nr 2, 8-9.

Okólnik w sprawie przyjmowania członków SCNNSP do Domu Zdrowia w Zakopanem, 1925, Nauczyciel Polski, nr 10-11, 9.

Opieka lekarska w naszym Domu Zdrowia w Zakopanem, 1926, Nauczyciel Polski, nr 4: 12.

Perła plaż polskich, 1935, Nauczyciel Polski, nr 8, 9. Po zjeździe, 1925, Nauczyciel Polski, nr 6, 6.

Przebieg $i$ uchwaty naszego zjazdu, Z życia Stowarzyszenia, 1928, Nauczyciel Polski, nr 9, 7.

Samopomoc Koleżeńska, 1934, Nauczyciel Polski, nr 8,15 .

Samopomoc Koleżeńska. Z życia Stowarzyszenia, 1934b, Nauczyciel Polski, nr 9, 14.

Spetnijmy swoje zobowiązanie!, 1926, Nauczyciel Polski, nr 8-10, 4.

Sprawozdanie z dziatalności Zarządu Gtównego Stowarzyszenia Chrześcijańsko - Narodowego Nauczycielstwa Szkót Powszechnych za rok 1937, 1938, Nauczyciel Polski, nr 10, 6-7.

Sprawozdanie z działalności Zarządu Głównego za rok 1926, 1927, Nauczyciel Polski, nr 7, 7-28.

Sprawozdanie Zarządu Gtównego z działalności Stowarzyszenia Chrześcijańsko - Narodowego Nauczycielstwa Szkót Powszechnych za rok 1933, 1934, Nauczyciel Polski, nr 8, 9.

Sprawozdanie Zarzadu Głównego z działalności Stowarzyszenia Chrześcijańsko - Narodowego Nauczycielstwa Szkót Powszechnych za rok 1930, 1931, Warszawa.

Sprawozdanie Zarzadu Głównego z działalności Stowarzyszenia Chrześcijańsko - Narodowego Nauczycielstwa Szkót Powszechnych za rok 1935, 1936, Nauczyciel Polski, nr 8, 7.

Sprawozdanie Zarzadu Gtównego z działalności Stowarzyszenia Chrześcijańsko - Narodowego Nauczycielstwa Szkót Powszechnych za rok 1936, 1937, Nauczyciel Polski, nr 8, 7.

Sprawozdanie Zarzadu Głównego z działalności Stowarzyszenia Chrześcijańsko - Narodowego Nauczycielstwa Szkót Powszechnych za rok 1934, 1935, Nauczyciel Polski, nr 9, 1.

Sprawy Samopomocy Koleżeńskiej, 1930, Nauczyciel Polski, nr 15, 9. 
Stadnicki A., 2015, Wspomnienia, Wybór i opracowanie Józef Długosz, Nowy Sącz.

Statut Stowarzyszenia Chrześcijańsko - Narodowe Nauczycielstwa Szkót Powszechnych uchwalony na walnym zjeździe Delegatów Stowarzyszenia $w$ Warszawie w dniach 25-26 kwietnia 1924 roku i uzupetniony na walnym zjeździe Delegatów Stowarzyszenia w dniach 17 - 18 kwietnia 1925 r., 1928, Warszawa.

Usiądek J., 1998, Stowarzyszenie Chrześcijańsko Narodowe Nauczycielstwa Szkót Powszechnych 1921 - 1939, Olsztyn.

Wakacje u siebie, 1935, Nauczyciel Polski, nr 12, 8.

Wczoraj i dziś Stowarzyszenia Narodowo - Chrześcijańskiego Nauczycielstwa Szkót Powszechnych, 1937, Poznań.

Węglarz B., 2008, Stadniccy w Szczawnicy, Kraków.

Witkowski J., 1992, O osadnictwie w okolicach Szczawnicy, o Sewerynówce, domu nauczycielskim $i$ wybudowanej tam kaplicy, Z Doliny Grajcarki, $\mathrm{nr} 8,3$.

Z naszego Zjazdu, 1932, Nauczyciel Polski, nr 14, 4. Z życia Stowarzyszenia Oddziału Lwowskiego, 1934, Nauczyciel Polski, nr 6, 5.

Z życia Stowarzyszenia, 1925, Nauczyciel Polski, nr 7, 11.

Z życia Stowarzyszenia, 1927a, Nauczyciel Polski, nr 4,7 .
Z życia Stowarzyszenia, 1927b, Nauczyciel Polski nr 5,5 .

Z życia Stowarzyszenia, 1928, Nauczyciel Polski, nr 9, 8.

Z życia Stowarzyszenia, 1929, Nauczyciel Polski, $\mathrm{nr} 2,5$.

Z życia Stowarzyszenia, 1931a, Nauczyciel Polski, nr 14, 8.

Z życia Stowarzyszenia, 1931b, Nauczyciel Polski, $\mathrm{nr} 1,5$.

Z życia stowarzyszenia, 1932, Nauczyciel Polski, nr $12,7-8$.

Z życia Stowarzyszenia. Zarzad Gtówny, 1935, Nauczyciel Polski, nr 7, 9.

Zasady wychowania dla Polski, 1922, Nauczyciel Polski, nr 18, 73.

Ze sprawozdania Stowarzyszenia za rok 1938, 1939, Nauczyciel Polski, nr 11, 3.

Zmiana lekarza w Modrzejowie, 1936, Nauczyciel Polski, nr 17, 11.

web-o1, Jastrzębia Góra, Ośrodek Wypoczynkowy Fregata, www.jastrzebiagora.nadmorzem.net, (dostęp 20.08.2017 r.).

web-o2, Zburzono legendarny zakopiański pensjonat, www.zakopanedlaciebie.pl (dostęp 20.08.2017).

\title{
Healthcare homes and resort hotels of the Christian National Association of Common School Teachers in the interwar period
}

\begin{abstract}
The years of partitions, especially the period of the First World War, caused considerable deterioration of the health of the Polish population. The situation required radical action and heavy financial expenses. Meanwhile, the newly reborn Polish state had very few resources to provide fully professional healthcare. Therefore, different types of working professionals were expected to participate in the nationwide fight for citizens' health and leisure. The first Polish community which strongly supported the Polish government in this area were teachers grouped in several organisations and associations. Among them was the Christian National Association of Common School Teachers, created in September 1921 as a result of the merger of nine teacher organisations. The result of the voluntary taxation of the representatives of that patriotic and national organisation was the establishment and maintenance of healthcare homes in Sewerynówka, near Szczawnica, and in Zakopane, as well as the resort hotel in Jastrzębia Góra. Some of these centres are still functioning.
\end{abstract}

\section{Keywords}

healthcare home, resort hotel, preventat, Interwar Period, association, teachers 